victim or the assailant. It is interesting to note that Paris and Fonblanque, 130 years ago, foresaw the possibilities in this direction, but, foreseeing also the immense widening of the field which it entailed, they deemed it wiser to concentrate on more purely medical matters. To-day, however, the field of forensic science has been widely explored, and on many occasions we must call for the co-operation not only of the surgeon, the obstetrician, the anatomist, the pharmacologist, etc., but also of the botanist, zoologist, entomologist, physicist, chemist, geologist, and others. It is not part of the medico-legal expert's task to be competent in all these spheres-that is an impossibility for any man; but it is incumbent upon him to realize just when it appears proper to invoke the co-operation of one or more of these specialists. There was perhaps a time when the progressive development of medical specialization seemed likely to render the medical jurist out of date or redundant. It seems to me that it is being more clearly realized to-day that that view, if it was ever seriously held, is a misapprehension, and that the need for sound teaching in forensic medicine and for the existence of specialists in the subject is greater to-day than it ever was. The study of forensic medicine should not constitute a major hurdle for the student on his long route to graduation, but it remains true to say that his medical education is incomplete if he finishes his studies without having had some instruction in the subject. I am very gratified to note that this view seems to be increasingly shared among those responsible for the programme of studies at the various medical schools, and that in a number of cases steps have been taken to establish a new department or to strengthen an existing one. I believe that the policy which this reflects is thoroughly sound, and I hope we may see still further developments in this direction.

I am greatly indebted to Dr. F. S. Fiddes, of my department, for his help in the preparation of this paper.

\section{SUCCESSFUL BREAST-FEEDING*}

BY

\section{F. CHARLOTTE NAISH, M.D.}

)

At all times "fashion" has played a considerable part in the degree of breast-feeding. From being unfashionable in the eighteenth and nineteenth centuries, breast-feeding passed at the beginning of the present century into another phase in which most women fed their babies. The common practice, however, was to feed every two hours-and sometimes as often as half-hourly. No doubt there were "feeding problems"; but there is no reason to suppose that breast-feeding was a general failure. In order to solve the problems some observers --among the first was Waller (1915)-established the existence of a conditional periodicity in the breasts. At once an army of non-thinkers set up a fashion of rigid regimentation-a fashion which was hollow and stupid, as often there was no feeding problem to solve. It produced a reaction, since the 1939-45 war, in the shape of " demand feeding," which, slavishly followed by unin-

* Read in opening a discussion in the Section of Child Health a the Annual Meeting of the British Medical Association, Liverpool, 1950. telligent people, probably leads to just as much dyspepsia and trouble as the clockwork method. In my opinion all such fashions originate with people who read but do not understand the findings of original observers. The truth lies, as is often the case, on the middle road; and each nursing couple is an individual problem, to be studied as such.

The fashions I have mentioned have spread from medical circles to the general public. There are some that are more or less limited to professional circles. The large number of babies being underfed at the breast led Pritchard (1913) and others, following Pierre Budin (1900), to introduce test-feeding as a method of safeguarding the infant's food intake. This also was reduced by non-thinkers to a set of rules to be slavishly followed, and provoked a reaction-too violent, as usual-so that now test-feeding and even regular weighing of young babies are being decried as " never necessary."

I have found that with increasing experience and study of infant feeding I can manage with much less testfeeding, and now use it only to solve a problem or to strengthen a mother's confidence. It would be quite another thing to recommend that attitude to others as a starting-point. I think they too should work their way to it.

All these violent fluctuations of practice are so many red herrings that obscure the real and unchanging problem. We are dealing with a race of women among whom there are good, medium, and poor milkers. We ought to know the proportion of these groups; but this is very difficult to discover from the data now available.

What is the significance of the figures shown in Table I ? The more I ponder them the more I am convinced that only two principles can explain them: success depends on continual supervision and on the

TABLE I.-Incidence of Breast-feeding

\begin{tabular}{|c|c|c|c|}
\hline Series & $\begin{array}{l}\text { Babies } \\
\text { Artificially Fed } \\
\text { at } 8 \text { Weeks }\end{array}$ & $\begin{array}{l}\text { Babies Still } \\
\text { Breast-fed } \\
\text { at } 3 \text { Months }\end{array}$ & $\begin{array}{l}\text { Babies Still } \\
\text { Breast-fed } \\
\text { at } 6 \text { Months }\end{array}$ \\
\hline Naish (1949) $(100$ cases).. & 21 & $\begin{array}{l}\% \\
67\end{array}$ & $\begin{array}{l}\% \\
65\end{array}$ \\
\hline püblished) & $17 \cdot 5$ & 71 & - \\
\hline Finlay (Spence, 1938) & - & 55 & - \\
\hline Brewis (Spence, 1938) & - & 58.4 & - \\
\hline $\begin{array}{ll}\text { Williams (1947) } & \ldots \\
\text { Hughes (1942) } & \ldots\end{array}$ & 22 & 73 & - \\
\hline $\begin{array}{ll}\text { Hughes (1942) } & \ldots \\
\text { Lewisham* } & \ldots\end{array}$ & $\overline{15}$ & 41 & 二 \\
\hline Southport* & 76 & - & - \\
\hline West Sussex* & 20 & - & 一 \\
\hline $\begin{array}{l}\text { Cornwall* } \\
\text { Waller }(1946)(100 \text { treated }\end{array}$ & & T & - \\
\hline antenatally) ${ }^{+}$ & 一 & 87 & 83 \\
\hline $\begin{array}{c}\text { Waller }(1946) \\
\text { treated antenatally }) \dagger\end{array}$ & - & 65 & 42 \\
\hline
\end{tabular}

* Quoted in Maternity in Great Brituin. Oxford University Press, London. +200 cases in same hospital.

encouraging attitude of those in attendance; and success breeds success through the altered expectations of the mothers in the district. If this is so, the figures reveal next to nothing about the proportions of good and bad milking strains in the population.

Dr. Waller obtains the best results because, alike in the antenatal phase, in the puerperium, and in the follow-up of the infants, his workers are a united team. 1 cannot get such good work done in the puerperium, because I am dependent on a variety of nurses, in different nursing-homes or on different districts, who are not directly under my control. For the rest of the country also the results vary with the attitude of the 
nurses and medical attendants, whether they are general practitioners or in the welfare services.

In this connexion I would like to say that I think doctors are too much influenced by their own family experiences, and make sweeping generalizations based on that exceedingly flimsy evidence. The fathers of children who have been adequately and easily breast-fed are inclined to attribute all difficulties to the mother's psychology. They may do even worse, and not supervise the progress of the babies, so that women less fortunate than these doctors' wives are left to cope with underfed infants. The fact that these babies improve as soon as they are artificialiy fed makes their mothers eternal devotees of the bottle system. Many such mothers could feed their children on the breast in part, and would gain much satisfaction from doing so.

At the other end of the scale is the doctor-father of children who were not breast-fed after the first week or two. He often seems impelled to gloss over his wife's physiological failure; so he advocates $100 \%$ artificia] feeding, and says it is all nonsense that breast-fed babies are better.

One has to reply to these sceptics-not with any great hope of convincing them, because they have such powerful emotional reasons for scepticism, but in the hope of counteracting their influence.

We have travelled far from the days at the turn of the century, when the main problem was dirty milk and the fatal enteritis it gave rise to. Such dangers have not disappeared altogether, but they now take a lower place than the incidence of upper respiratory infections in the second six months of life. Grulee et al. (1935), in Chicago, have demonstrated, on the basis of a very large hospital series, how much more the artificially fed child is liable to such infections. I have been able to confirm this in the sphere of general practice by studying a continuous series of babies and finding that those who were artificially fed required nearly five times as many domiciliary visits for illness as those who were breast-fed for more than three months (Naish, 1949). It is worth particular mention that social class, which affects the infant mortality so much in the country at large, did not have any effect on the morbidity in this series (Table II), which was entirely dependent on the extent of artificial feeding.

\begin{tabular}{|c|c|c|c|c|}
\hline Social Group* & & Babies & Visits & Visits per Baby \\
\hline \multicolumn{5}{|c|}{ Babiss breast-fed over three months } \\
\hline $\begin{array}{l}\text { I and Ii } \ldots \\
\text { III } \\
\text { IV and V } \ldots\end{array}$ & $\begin{array}{l}\cdots \\
\cdots \\
\cdots\end{array}$ & $\begin{array}{l}13 \\
42 \\
12 \\
\end{array}$ & $\begin{array}{l}29 \\
50 \\
14 \\
\end{array}$ & $\begin{array}{l}2 \cdot 23 \\
1 \cdot 19 \\
1 \cdot 17 \\
\end{array}$ \\
\hline Total & $\cdots$ & 67 & 93 & $1 \cdot 39$ \\
\hline \multicolumn{5}{|c|}{ Babies breast-fed under three months } \\
\hline $\begin{array}{l}\text { I and II } \ldots \\
\text { III } \\
\text { IV and } \mathrm{V} \\
.\end{array}$ & $\begin{array}{l}\cdots \\
\therefore \\
\cdots\end{array}$ & $\begin{array}{r}7 \\
18 \\
8\end{array}$ & $\begin{array}{r}43 \\
102 \\
44\end{array}$ & $\begin{array}{l}6 \cdot 14 \\
5.67 \\
5 \cdot 50 \\
\end{array}$ \\
\hline Total & . & 33 & 189 & 5.73 \\
\hline
\end{tabular}

I would urge other general practitioners to make a similar study of their infant patients : this cannot be done by paediatricians or infant-welfare personnel. It provides the most general measure of morbidity that I think anyone could devise. And it is calculated to convince them, as no amount of literature can do, that breast-feeding still has the advantage, whether it can be accounted for or not.

\section{The Importance of Confidence}

Given that breast-feeding, where it is possible, is a good thing, what can be done to improve the feeding powers of our medium and poor milkers? On the side of pure scientific research much remains to be done, and we ought never to lose touch with the agricultural experts, who are also concerned with these problems. Although we cannot avail ourselves of their easy way out-inasmuch as when they meet a persistently poor milking strain they cease to breed from it-yet their experiments are sure to be of help to us in our problems.

We, as clinicians, can do little in such matters except ask the questions and wait, patiently or impatiently as we please, for someone to give us the answers. In the meantime we have to make the best use of the knowledge we already have - and in the best place. I am convinced that we neglect broad psychological factors and small technical details, and that sometimes the two meet. Again we should observe the cow which, because of some upset of her routine, refuses to "let down her milk." We should then better appreciate the psychological care required in dealing with newly delivered mothers. (At this point let me say that by this rather tired word "psychological" I mean nothing very technical. What is wanted is sometimes common humanity, sometimes common sense.)

The willingness of general practitioners to give up the preventive side of their work with infants and the antenatal side of their work with mothers has bad effects on everyone concerned; but perhaps it is best to begin with the bad effects on the medical attendants themselves. They begin by looking at only one part of the problem. I have known it to be decided that nothing could be done for a certain baby because he had a " perfectly hopeless mother." The clinician who arrives at such a decision is regarding the baby and the mother as two distinct individuals-whereas surely it is obvious that there can never be any approach to the child except through the mother (and perhaps the father). But the mother had never been his concern, and it may well have been that the appearance of non-cooperation on her part was engendered by the fact that she was dealing with a stranger. We have all met the mother who prevaricates because she fears criticism. We have advanced far enough in our understanding of children to know that the fear of criticism and the resentment of ridicule may set an intelligent and affectionate child on the road to delinquency. We have next to learn that mothers and expectant mothers should be treated very like children-helped rather than criticized, led rather than ordered, and encouraged on every small success.

I must give a recent illustration of the emotional instability of motherhood. A junior nurse remarked to an elderly mother, one day when her milk supply was low, "Poor dear little thing! You're starving it, mother." This silly remark, thoughtless and pointless, destroyed all the confidence gradually built up in the mother during the antenatal phase, and brought her to a state bordering on hysteria, in which she believed the nurses thought she was doing it on purpose. In consequence, by the third week, when she returned to my charge, she really was starving the baby. By carefully re-establishing her confidence, and introducing a complement "as a temporary measure," I was able to get this mother calm again and to re-establish full breastfeeding, which was maintained for six months. 
Such cases make it plain that the successful rearing of a baby at the breast may depend aimost entirely on seif-confidence, and this in turn depends on faith in the support of a familiar adviser. A woman supervised by many different authorities finds it hard to develop this confidence, either in herself or in her advisers. It would have been very hard to re-establish the confidence of this elderly mother, brooding on the nurse's supposed criticism, if I had not attended her antenatally.

Thus, starting with the bad' effects of interrupted supervision on the medical attendants, we have come smoothly round to the bad effects on the mother, who needs encouragement and confidence and cannot get them from a succession of strangers. On the other hand, one of the ways in which a real family doctor can help the mother is to arrange for her to meet some of his other mothers, both successful and unsuccessful at breast-feeding, and discuss the outlook with them. $\mathrm{He}$ will probably not be able to do this if his mothers are taking their feeding problems to the health authority's clinic; so that antenatal preparation is not so good when the infant welfare is left to others. Everything is interconnected.

\section{Physical Difficulties and their Management}

At the same time that the psychological preparation is begun the breasts should be thoroughly examined, and as a rule they are not. I have seen doctors examine the heart and not notice the left breast while doing so. If this is because they do not expect to be concerned with the feeding, then it is due to the discontinuity. If it is because the condition of the nipples is thought to be a minor technical detail, then it is an i'lusion of the moment. A retracted nipple must be treated from the first month if it is not to be a bar to feeding; so it is no detail. And if neglect, or mistaken treatment of the breasts, leads to a woman's trying to feed with a cracked nipple, that is.neither a detail nor a technicality. 'It is painful enough to be regarded as one of the major psychological problems.

Yet another post-natal difficulty whose treatment must be begun antenatally is the "congestive phase" in the first week: Dr. Waller has taught us to mitigate this by the hand-expression of colostrum in the last two months. I am convinced by experience that he is entirely right in respect of both the danger to lactation which this phase represents and the advisability of guarding against it.

Before the congestive phase is upon us we are faced with a problem which is both technical and psychological: the problem of whether the baby should suck before the milk "comes in." I call this partly psychological, because the usual reason for putting babies up to the breast is "so that they can learn to suck"-as though that was not the one thing they already knew, and as though anyone could teach them if they did not. Yet this idea that a reflex will be forgotten in three days if it is not brought into play is so firmly fixed that very often, where one has had no opportunity to train a team, one has to give way to it. However, if the baby show's any reluctance I will not have it pressed, believing that many newborn babies are suffering from a slight concussion and that over-stimulating them produces an irritability which makes the mothers apprehensive and the babies more and more tiresome. It does no harm to leave a full-term baby undisturbed until the third day. In any case, if practice feeds are done, I insist that they shall be short, since long sucking at this stage is a potent cause of cracked and sore nipples.
The congestive phase may follow almost immediately on the relatively milkless phase. My own method of dealing with it differs somewhat from Dr. Waller's for the reason that underlies most of our differences-the fact that a general practitioner cannot secure the same team-work. I warn the mother that if it occurs it will come on very quickly, and advise her to use the baby to get the milk away by frequent short.feeds. I find that the baby will usually get away enough milk to establish a flow at a level sufficient for his particular needs. If the baby does not reduce the congestion enough, then the mothers follow the frequent sucklings by short spells of hand-expression. I find them willing and quick to learn the technique and to become efficient at it, but that short spells are less tiring for them than long sessions at less frequent intervals. I think it will be evident to you how important it is, during the two or three days that this phase lasts, that a spirit of confidence should have been built up beforehand.

It must be clearly understood that the mechanisms of the secretion and outflow of milk are quite separate. Congestion arises when there is some interference with or slowing down of the process of outflow. In other words, secretion goes on but the outflow or expulsion of milk does not keep level with it-therefore the breast becomes "congested." The afferent impulse for expulsion of milk is through the sympathetic nerves mainly at the nipple, though other parts of the breast, when stimulated with light touch, can set off the mechanism. At the bra:n centre the efferent impulse is presumably hormonal and allied to oxytocin. At one time it was thought that the expulsive efforts of the alveoli and ducts were caused by smooth muscle, but Richardson (1950) has shown that there is no smooth muscle in these tissues. The contractions take place in myo-epithelial cells: Dr. Waller holds the theory, and a very reasonable one it is, that, when congestion is allowed to develop to a severe degree and continue for more than a short space of time, these myo-epithelial cells become overstretched and are therefore, temporarily at any rate, paralysed. This, he says, accounts for the early failure of lactation or, as I term it, the " third-week drop."

If the congestive phase has not been properly dealt with it is. usually in the third week that lactation fails. Even if that difficulty has been surmounted there is usually a drop in the third week-partly because of the combined effect of the mother's return to her duties and the sudden withdrawal of the nurse's advice and support. In my book I have called this drop "physiological": it occurred with such frequency that I thought it was so. I have since found, after closer supervision at this stage, that it need not occur; but nevertheless it is wise to be on the alert against it. Temporary complementary feeding is the remedy, and should be started without delay.

There is another point which has both a technical and a psychological aspect. Many doctors and nurses are still convinced that once you begin complementary feeding you are well on the way to artificial feeding. In practical experience I have disproved this contention over and over again. My mothers often use complementary feeding in the third and fourth weeks and are able to go back to full breast-feeding afterwards. Without any exception I insist that the complement be given with a spoon. The psychological side to the matter is that those who give complementary feeds and cannot withdraw them are precisely those who give the complement from a bottle. Yet nothing will persuade them that the two facts are connected. 


\section{Organization of Practice}

It will, I think, begin to be plain that what I consider essential for achieving successful breast-feeding is not new. It is, in fact, a return to the original idea of a general practitioner of medicine. In this respect I do not wish to appear to decry the specialist doctor any more than I would decry the specialist barrister; but, whatever the faiings of local magistrates, no one suggests that K.C.s specializing in some one branch of the law should plead in courts of first instance. What now happens in medicine, however, is very nearly that. There is no need for a pregnant woman to see her doctor at all. So long as she feels well she can wait till her pregnancy is beyond reasonable doubt and can then be attended by various local government officials-each doing his own little piece-until the child is a year old. She may remember to register the new baby on the general practitioner's list; she is just as likely to forget. The reason why this seems inferior to the familydoctor system is, in its broadest terms, this : the human infant being so immature and helpless, the process of reproduction is not even physically complete until a child can move about unsupported and feed itself. All that happens before that is a unity, and its different phases are emphatically not watertight compartments.

There is nothing in modern conditions to prevent the old system from working except the failure to realize its merits and advantages to all parties. This is how it can be done.

A special time should be set aside for antenatal work. Before the introduction of the Health Service the clinics offered two advantages: they were a free service, and they segregated the expectant mothers from the sick. Having allocated a time for antenatal work before the Health Service began, I am able to say definitely that the segregation was just as important as the absence of charge.

The second step is to extend the period of close domiciiiary supervision up to the end of the fifth week. There is, of course, no fee to be recovered for doing that, and if the doctor is just a medical shopkeeper it is not worth while. To realize how very worth while it really is, the doctor needs to be aware how often feeding difficulties or the failure of lactation arise between 14 and 35 days; he needs the humanity to estimate the burdens of a woman at that time ; and he needs the foresight and imagination to appreciate what dividends careful supervision of the first year of life can pay. If he looks at the problem that way, it will seem to him good practice to make two calls a week on his new babies, armed with a pair of portable scales, and attend to any question (not excluding the good laundering of napkins) that the mother wants to raise.

The third step is to ask the executive council's permission to limit an afternoon surgery to mothers attending with infants and pre-school children. Now that they are among one's "contract patients," this is viewed quite sympathetically compared with the days of national insurance of workers only. In view of the number of women who do not book a doctor for their second or later labours, this "clinic" - the patients will insist on using that word-must be open to all mothers on the practice, however the confinement was conducted. One of the advantages to the mother is that immunization and vaccination can be done at this session, and the mother's ailments be attended to, so long as they do not involve a gynaecological examination. It is a boon to a busy mother not to have a separate journey at a separate time in order to get treatment for herself. All this makes a busy afternoon, and some help is essential. It is very pleasant to have to report that the medical officer of health has recognized this work as something that the local health authority would have to do if it were not done as part of the practice, and that the health committee has allowed me the free services of a health visitor to help me with the weighing and the records. These are strong grounds for saying that general practitioners who are inclined to take up this work will not find the public health authorities against them, but inclined to help them.

\section{Conclusion}

This style of practice arises from the determination to achieve successful breast-feeding and from an increasing realization that that is not an isolated problem. I have said that it yields dividends. First under this heading comes the observation, already stated, that what seem to be "extra" visits and consultations in the first six months are really substitutes for the treatment of coughs and colds a year later.

Supervision of the infant, however, has much more interest. The second gain is that by supervision of the infants closer and pleasanter personal relations in the practice are built up. The parents cease to be people who just want to get something out of the doctor, once he plays an intimate and continuous part in an aspect of their lives of such emotional importance. In my own practice the mothers have lately formed a large voluntary club, self-supporting and self-governing, which meets once a month to discuss any subject that might conceivably affect their children's health. Its success can best be judged by the fact that the fathers became jealous and started a parallel organization.

The third profit is the satisfaction gained from developing a prophylactic outlook-in simple words, an interest in health-among people who otherwise glory in "serious illness."

The fourth profit is in the fascinating lines of study and opportunities for research which arise from a more continuous observation of one's patients-starting even prenatally.

Finally, if some general practitioners are in the future to be linked with teaching schools or with departments of social medicine, it will probably be those who do prophylactic work.

\section{REFERENCES}

Budin. Pierre (1900). Le Nourisson. Doin, Paris.

Grulee, C. G., Sandford, H. N., and Schwartz, H. (1935). J Amer. med. Ass., 104, 1986.

Hughes, Enid L. (1942). British Medical Journal, 2, 69.

Maternity in Great Britain. Oxford Univ. Press, London. 1948.

Naish, F. C. (1949). Lancet, 1, 146.

Pritchard, Eric (1913). Brit. J. Child. Dis., 10, 420.

Richardson, K. C. (1950). British Medical Journal, 2, 350.

Spence, J. C. (1938). Ibid., 2, 749.

Waller, H. K. (1915). Lancet, 2, 115.

- (1946). Arch. Dis. Childh., 21, 1.

Williams, E. J. (1947). Publ. Hlth, 60, 201.

In a very recent issue of the Journal of the American Dental Association, according to the United States Information Service bulletin U.S.A. in Review, is a description by Dr. Robert B. Black, of Corpus Christi, Texas, of how he drills teeth with compressed air, instead of using a mechanical drill. The air stream carries a controlled quantity of small abrasive particles, and when the jet is directed against a tooth it rapidly cuts it away. He has had experience of over 2.000 cases for filling or other dental treatment, and claims that it is less disturbing to patients. It creates less fear and apprehension than the conventional burr, which gives rise to vibration (boneconducted noise) and to sensations of pressure and mechanical stimulation which are extremely unpleasant and fear-provoking. 